\title{
RACIALISM SLAVERY AS REFLECTED IN PAUL LAURENCE DUNBAR'S POEMS TO SOCIAL LIFE
}

\author{
NARLIUS REINAL ERIANTO ${ }^{1}$ \\ MAC ADITIAWARMAN ${ }^{2}$ \\ FETRI RENI ${ }^{3}$
}

Volume 1 Nomor 1

JILP

ISSN: 2581-0804

E-ISSN: 2581-1819

\begin{abstract}
Slavery to Social life's Racialism analyzes the disclosure of a black-life tragedy of slavery and racism in their social life. The author takes data from Dunbar's poems: We Wear the Mask, The Debt, Sympathy, Life's Tragedy and The Paradox. In these five poems the author analyzes how slavery that has taken place in America on the basis of the five poems of Dunbar, some kind of racism that the author finds in the five poems of Dunbar, and the result of social slavery to the black social life in America that the author finds in The five poems of Dunbar.

This research method is descriptive qualitative, which try to explain about correlation between writer life background which pour through poetry and its influence to human social life. In analyzing the five poems of Dunbar, the author uses a psychological approach that discusses the psychology of human personality

the id, ego, and the human superego. The main source of data obtained from the five poems Dunbar namely: We Wear the Mask, The Debt, Sympathy, Life's Tragedy and The Paradox. Other sources come from articles and internet books.

From the analysis of the five poems of Dunbar, the authors found that (1) Slavery and human rights abuses against blacks in America are reflected through the five poems of Dunbar. (2) The author finds some form of racism such as the occurrence of discrimination and persecution that caused the suffering of blacks in America on the basis of the fifth poems of Dunbar and (3) There have been proven consequences of the slavery experienced by blacks in America that the author has discovered from the fifth Dunbar's poetry is like feeling oppressed or experiencing the mental stress that causes blacks in America to suffer.
\end{abstract} which is the theory of Sigmund Freud including

Keywords: slavery, racism consequence of slavery.

\begin{abstract}
ABSTRAK
Racialism Slavery to Social life ini menganalisis tentang pengungkapan sebuah tragedi kehidupan orang-orang kulit hitam tentang perbudakan dan rasialisme yang terjadi didalam kehidupan sosial mereka. Penulis mengambil data dari puisi Dunbar yaitu: We

Wear the Mask, The Debt, Sympathy, Life's Tragedy dan The Paradox. Di dalam kelima puisi ini penulis menganalisis bagaimana perbudakan yang telah terjadi di amerika berdasarkan kelima puisi Dunbar, beberapa macam dari rasialisme yang penulis temukan di dalam kelima puisi
\end{abstract}


Dunbar, dan akibat dari perbudakan sosial terhadap kehidupan sosial orang kulit hitam di amerika yang penulis temukan di dalam kelima puisi Dunbar tersebut.

Metode penelitian ini adalah deskriptif kualitatif, yang mencoba menjelaskan tentang korelasi antara latar belakang kehidupan penulis yang di tuangkan melalui puisi dan pengaruhnya terhadap kehidupan sosial manusia. Di dalam menganalisis kelima puisi Dunbar ini penulis menggunakan pendekatan psikologi yang membahas tentang psikologi kepribadian manusia yang merupakan teori dari Sigmund Freud meliputi id, ego, dan superego manusia. Sumber data utama diperoleh dari kelima puisi Dunbar yaitu: We Wear the Mask, The Debt, Sympathy, Life's Tragedy dan The Paradox.
Sumber- sumber lainya berasal dari buku-buku artikel dan internet.

Hasil analisis dari kelima puisi Dunbar, penulis menemukan bahwa (1) Terjadi perbudakan dan pelanggaran Hak Asasi Manusia terhadap orang- orang kulit hitam di Amerika yang dicerminkan melalui kelima puisi Dunbar. (2) Penulis menemukan beberapa bentuk rasisme seperti terjadinya diskriminasi dan penganiayaan yang menyebabkan penderitaan pada orang kulit hitam di Amerika berdasarkan kelima puisi Dunbar dan (3) Telah terbukti beberapa akibat dari perbudakan yang dialami oleh orang kulit hitam di Amerika yang telah penulis temukan dari kelima puisi Dunbar seperti merasa tertindas atau mengalami tekanan jiwa yang menyebabkan orang kulit hitam di Amerika menderita.

\section{Kata Kunci: perbudakan, rasisme, akibat dari perbudakan}

\section{BACKGROUND OF THE PROBLEM}

Literature is something that refers or relates to literary property (the set of knowledge relating to the write and read well, or the art of poetry and grammar). So literary work is the creation of communicative intent to conveyed by the author for aesthetic purposes. These works often tell a story, either in the first or third person, with the plot and throught the use of various literary devices associated with their time.

The major literature is poetry that a form of literary art which uses aesthetic and rhythmic qualities of language to evoke meanings in been distinguished meanings in addition to, or in place of, prosaic ostensible meaning. Poetry has traditionally been distinguished from prose by its being set in verse prose is cats in sentences, poetry in lines a syntax of prose dictated by meaning, whereas that of poetry is held accros mater or the visual aspects of the poem. A poetry as form literary work is the most concentrated and considered because a poetry has style unique word. Poetry is related to human social life because it deals with death, love, racial, happiness, and hateness.

The reasons why the writer chooses poetry because poetry likes other literary works such as novel, drama, and cover many aspects of life. Poem is concern with feeling, reaction, and attitude. Besides that, poem cover about social life and culture. Through the appreciation of poems is an artic of life and experienced of human life. In relation with the statement above Hudson (1983:31) says : "When people study about literature, there is one thing to be consider, it is national spirit loaded in it, in which it embodies and express the changing spirit of successive ages". This is real social value in poetry as a work, as writes in his book (1983:92): "It is important to hold fast to this : that poetry is at bottom of criticism of life, his powerful applications of ideas to life, to the question: "How to life" from the quotation above, the writer conclude poetry is not only as literature but poetry as a study of society. Poetry is a critic of life and experienced of human life.

In this research, the writer want to analyse Dunbar's poems: We wear the mask, The debt, Sympathy, Life's Tragedy, and The Paradox are based on the psychology aspect between the poetry and his poems, to which he takes as his topic: Racialism Slavery as reflected in Paul Laurence Dunbars poems to social life. 


\section{METHOD OF RESEARCH}

This research method is descriptive qualitative, which try to explain about correlation between writer life background which pour through poetry and its influence to human social life. In analyzing the five poems of Dunbar, the author uses a psychological approach that discusses the psychology of human personality which is the theory of Sigmund Freud including the id, ego, and the human superego. The main source of data obtained from the five poems Dunbar namely: We Wear the Mask, The Debt, Sympathy, Life's Tragedy and The Paradox. Other sources come from articles and internet books.

As the writer has mentioned before, the scientific approach that is used in this analysis is psychological approach. This method is applied in systematic procedures, which are mainly to collect the psychology material as the basic study to analyze the poems by Paul Laurence Dunbar's.

\subsection{Method of Collecting Data}

In the collecting data, the writer applies library research. It means that the writer applies the data which the writer takes from library and other written material from book store or even internet. Rasmuson (2014:310) states :

Library research involves the step-bystep process used to gather information in order to write a paper, create a presentation, or complete a project. The research process itself involves indentifying and locating relevant information, analyzing what you found, and then developing and expressing your ideas.

Though this library research activity, the writer gains some aids to developed the research theory and even the perfection of problem analysis, or the modification for the research problem which is done before. Successful library research is defined as the systematic study and infestigation of some aspect of library and information science where conclusions are based on the analysis data collected in accordance with pre-established research designs and methodologies. In order to gain more information, the writer also executes the internet research as the support the data from library research. In library research, gather complete information the first time. Document the sourches carefully and take notes with page numbers. If the researcher has to refer back to the source, it will save time if this information is readity available and it will be needed it for your bibliography or "works cited" list.

\subsection{Method of Analyzing Data}

In analyzing the data the information from data colection is processed and presented in form of thesis. In appli the writer uses qualitative method. Qualitative research is designed to reveal a target audience's range of behaviour and the perceptions that drive it with reference with specific topic or issues. Qualitative method is about exploring issues, understanding phenomena, and answering question by analyzing and making sense of unstructured data.

\subsection{Technique for Collecting the Data}

Colecting the data by using the library research. The writer collects some books that are related to the analysis to support the poem analysis and reads them many times till the writer can takes the ideas from them.

\subsection{Technique for Analyzing the Data}

Then, in data analysis, the writer makes a good relationship and argumentation from the books to the problem. If the data are not complete enough, the writer explains the phenomena with his own words as clear as possible. He applies libbrary research by colection and reading the book that are related to the topics beside the poetry itself as the main source. 


\section{RESEARCH FINDING}

There are 3 (three) Racialism Slaveries as reflected in Paul Laurence Dunbars poems to social life, there are; kind of slavery in Paul Laurence Dunbar poems, kind of racial that can be found in the poems, and the effects of social slavery to social life that can be found in the poems. It is possible, that there are some other issues can be appreciated through the poems. In this occasion, the three mentioned above seems appropriate to be discussed since they are considered as an integrated unit. One issue can influenced by another. To figure out the issues, the writer not perform it separated per poems, but in the whole of five poems. This is because one issue may be found in more than poems, or in another case, one poems in fact loads more than one of these social problems. So that, when a certain issue is talked over, directly it be pointed to any poems.

3.1 The Slavery happen in America as Reflected in Dunbar's Five Poems

Slavery in America began when the first African slaves were brought to the North American colony of Jamestown, Virginia, in 1619 , to aid in the production of such lucrative crops as tobacco. Slavery was practiced throughout the American colonies in the 17th and 18th centuries, and African-American slaves helped build the economic foundations of the new nation. The invention of the cotton gin in 1793 solidified the central importance of slavery to the South's economy. By the mid-19th century, America's westward expansion, along with a growing abolition movement in the North, would provoke a great debate over slavery that would tear the nation apart in the bloody American Civil War (1861-65). Though the Union victory freed the nation's 4 million slaves, the legacy of slavery continued to influence American history, from the tumultuous years of Reconstruction (1865-77) to the civil rights movement that emerged in the 1960 s, a century after emancipation.

The treatment of slaves in the United States varied widely depending on conditions, times and places. The power relationships of slavery corrupted many whites who had authority over slaves, with children showing their own cruelty. Masters and overseers resorted to physical punishments to impose their wills. Slaves were punished by whipping, shackling, hanging, beating, burning, mutilation, branding, and imprisonment. Punishment was most often meted in response to disobedience or perceived infractions, but sometimes abuse was carried out to re-assert the dominance of the master or overseer over the slave. Treatment was usually harsher on large plantations, which were often managed by overseers and owned by absentee slaveholders, conditions permitting abuses.

According to Lincoln (1859) in his social problems, "I think slavery is wrong, morally and politically. I desire that it should be no further spread in these United States, and I should not object if it should gradually terminate in the whole Union". It's means descrimination or difference of human being such as race, socially, politically, religion is wrong in world eyes moreover in God's eyes and not only occur in the United States but only in everywhere. It's same like in poems Paul Laurence Dunbar below:

This is the debt I pay

Just for one riotous day,

Years of regret and grief,

Sorrow without relief.

(The Debt 1-4)

In this poetry Dunbar describes about slavery are full of the regrets and the black people aware pay the debt with their life to be a slavery. Its so terrible with the american white buyed them to be a slavery and during of years employed them with unhumanity that just broken of their social life and full of regret and deeply profound sorrow so that the black people just can dreams to get a freedom and proper life.

It may be misery not to sing at all, And to go silent through the brimming day; It may be misery never to be loved, But deeper griefs than these beset the way. (Life's Tragedy 1-4)

The poem goes on talking about the tragedy of life, of how we as humans can get close to perfection but not yet achieve it life in misery and odd joys. This poem signifies humanity's want for emotions and feelings, even though it takes away the possibility for perfection. In this poem the writer also describes some suffering life that is not life what they hoping. There are something tragic to do, and so influence of their social life. In this poems any kinds word telling about tragedy and deeply sadness of the American black. 

We wear the mask that
grins and lies,
It hides our cheeks and
shades our eyes,
This debt we pay to
human guile;
With torn and bleeding
hearts we smile,
And mouth with myriad
subtleties.
(We wear the mask 1-5)

The author opens with the title of the poem, so we know this idea of wearing masks is mighty important since we've heard it twice already. We wear disguises that look nice ("grins"), but which are actually nothing but lies. Notice too the use of "we," which invites the reader to imagine himself as part of the poem's subject, making the meaning more universal. Since we're not sure who exactly that "we" is referring to, the writer assumes it more specifically refers to black Americans of the time, since Dunbar was an early pioneer of the Harlem Renaissance that came later in the 1920s.

In line 2 the people wearing them are "shading their eyes" (some figurative language here), which suggests they can't even "see" clearly and like wise can't be seen by others. There are some symbolisms then in line 2 that's getting at the essence of our humanity and the way express (or don't express) our true feelings. "Cheeks" often indicate how we're feeling (think of blushing) and "eyes" are thought to be the windows to our soul. So if both of these are "hidden," then we know we're not showing how we really feel.

Line 3 tells us that the people wearing these masks owe it all to "human guile." Fancy word check: "guile" simply means a sort of deceitfulness, not being real. but notice the speaker says "human guile," which again suggests that the poem can be applied to not just the black American struggle but also the general human struggle. After all, telling lies and being someone we're not is just a common part of daily life. And just like we saw in lines 1 and 2, these lines also have a lot of figurative language that's building upon the extended metaphor of masks representing human deception: "torn and bleeding hearts we smile."

Line 4 begins to develop the truths behind those masks and we get the sense that there's a lot of pain there. Those hearts are not just "torn" but also "bleeding" which really emphasizes the struggle and duality, so we're talking about opposites here). If someone is "torn," that usually means that there are two sides pulling at the same time. And if someone is "bleeding," the writer assume that that person is injured figuratively of course. And the writer understand the metaphor even more when we consider the imagery of a mask. On one side there's the disguise, and on the other there's the truth. That "smile" also builds upon that original description of the mask grinning and lying. Also it accents the duality in line 4 that starts with torn hearts and ends with a smile.

In this poetry Dunbar describes slavery in the colonial era, they (American black) always want to use the mask. Its the result happen inner depression and morality in their life and how to its can be a demanded for pretending to be happy although they employed to be a slave without salary. They persistently put smile in their face but in the soul happen some flaming terrifying of the spirit, for cover up all the thing they must be pretending with a smile without do something that opposite, because they aware they buyed just be a slave to employed by American white in a unhumanity and lose of the human right.

Speak to me gently or curse me,

Seek me or fly from my sight;

I am thy fool in the morning,

Thou art my slave in the night.

Paradox" is a lyric poem in which the author introduces his self and his poetry. This poem has a dilemma of being a human in a world that seems blurry and atrocious. The writer describes about mistreatment because happen desagreement from the different opinion and flaming of the spirit they have losen a human right and their life between life or be died they feel is so terrible.

Many things happen in our life such as one day we can feel as the king of the hill or some other day we feel as the worse human being in earth, but these little pieces are make us human. These are aspects that shape our life and determine our self strength. They are the path to find the true person that lies in us.

This, this indeed is to be accursed,

For if we mortals love, or if we sing,

We count our joys not by what we have,

But by what keept us from that perfect thing

.(Life's Tragedy 13-16).

In this poems, the writer describes about the struggle of the American black to defend of them freedom, that be prove how the black 
people want to divest some accursed themself to be a slave. The writer also see any reason why the black people want to fighting for get the freedom? That because the black people in America still have a hope, hope for free and get a human right. This poems there are have a moral massage not just for American black but for every human in the world. Dont believe some accursed is can't to solve, but wake up and fighting and change your mind to change your life be better than before.

3.2 Racialism that Found in Dunbar's Five Poems

Racism in the United States has been a major issue since the colonial era. Historically, the country has been dominated by a settler society of religiously and ethnically diverse Whites. The heaviest burdens of racism in the country have historically fallen upon Native Americans, Asian Americans, African Americans, Latin Americans, American Jews, Irish Americans and some other immigrant groups and their descendants. White Americans are by no means exempt from discrimination themselves, but it is less common. Major racially structured institutions include slavery, Indian reservations, segregation, residential schools (for Native Americans), internment camps, and affirmative action. Racial stratification has occurred in employment, housing, education and government. Formal racial discrimination was largely banned in the mid-20th century, and it came to be perceived as socially unacceptable and/or morally repugnant as well, yet racial politics remain a major phenomenon. Racist attitudes, or prejudice, are still held by moderate portions of the U.S population.

Racial discrimination is one of the most controversial problems in our society. The United States of America is one of the freest racist countries in the world. The America believed that all the people in the world should have the same opportunities, same respect, and equality. However, there still are certain groups of people that did not show their respect to the other, especially to the immigrants. There are more than a million people who come to the United States to fulfill their dream. However, due to certain people attitude, they have been treated unfairly. The story talks about discrimination and prejudice and it is also the one that most related the writer experience. All the people in this world are human beings and should be treated with equality. The story talks about discrimination and prejudice and it is also the one that most related the writer experience. All the people in this world are human beings and should be treated with equality. In the story the main character has been suspected on an unfamiliar street because he is an African American. This made him felt really bad because racial barriers are subtly maintained even when nobody seems to be taking an openly racist position. He felt he is an outsider. Obviously, certain groups of people had set a line between others and themselves. They believe the entire group of immigrants and different color of people is much lower than themselves in all the time. They are totally against it. The writer believed this story is named racism because the writer wants to get other people attention by writing this story. Racial discrimination might happen anywhere, to all the people, and at anytime. Nobody actually cares about it because people had already gotten used to it. However, this is what we called racism.

Often in this years, the issue of race and prejudice has dominated the news with reports of police brutality, struggles for civil rights, and demands for equality. Yet, while these demands for equality have come from different groups for different reasons, they are often undertaken to protest the practice of racial discrimination. In simple terms, racial discrimination is the practice of treating someone differently, or poorly, because of the color of his skin. For example, if you were interviewing two equally qualified applicants for the same job (one black and the other white) and you decided to hire the white person because you prefer to work with white people, you would have engaged in racial discrimination. The previous example might sound unfair or illegal (it's generally both), but it occurs a lot more than you might think. In some cases, people don't mean to do it and it's just an unconscious reaction, whereas at other times people intentionally discriminate. Regardless of whether it's conscious or unconscious, the best way to combat such an unfair practice is to know what it looks like and understand how it works.

According to Douglass (1845) he says: "the white man's happiness cannot be purchased by the black man's misery". It means every human must be equal in the world although from different of the social life. It seems like in poems by Paul Laurence Dunbar below:

Slight was the thing I bought,

Small was the debt I thought,

Poor was the loan at best

God! but the interest! 
(The Debt 9-12)

In this poem Dunbar uses the metaphor of borrowing money to buy something "slight," something not really worth much, but now he has to spend the rest of his life "paying" for his mistake. Related of in unjustice all ready they feel. They begining dreams how to get a freedom and hoping all the affliction to end but they just able doing with surrender all the thing to the God. So that God given a justice to them and its not lose of the human right.

Why should the world be over-wise, In counting all our tears and sighs?

Nay, let them only see us, while

We wear the mask.

(We wear the mask 5-9)

In this stanza starts with a rhetorical question (a question in which we don't expect someone to give us a real answer, like Who does that?). Rhetorical questions are usually used to prove a point, so we know the author is trying to emphasize what we've seen so far in terms of masks, suffering, hypocrisies, etc. Notice that this question has a slightly sarcastic tone to it, as if the author is suggesting that there's nothing "over-wise" about knowing the truth that's plain to see, with or without the masks.

We have more figurative language in line 7 too ("counting all our tears and sighs") that emphasizes the severity of the truth behind those masks. The words "all our" tell us that there are many tears and many sighs to "count" and they don't just belong to the author. So, by the second stanza we begin to more fully understand that the author represents a much larger group beyond himself, even if he doesn't provide specifics. What about the connotations of the word "counting"? Is there something tiresome about this word, as if there are too many to count? there's even something statistical about it, as if those tears and sighs are just numbers rather than real evidence of human suffering. Whichever way we choose to read lines 6 and 7 , we understand that there is real pain being felt by many people and that the world has a responsibility to recognize it. Perhaps the people wearing the masks also have a responsibility to themselves and each other to be honest about their suffering. Notice too that this couplet fits with the poem's first rhyme: "wise" and "sighs."

In lines 6 and 7 describe the rhetorical question that emphasized the truth behind the masks, while here in lines 8 and 9 we see just the mask and the people wearing them. So the author is saying here that, instead of the world seeing the truth, they see only the masks and the lies. And again the tone here in "let them" suggests that the world is being spared the truth, via ignorance, perhaps because the truth is harder to accept than the mask. The author is reminding us that the people wearing the mask need to be more honest about their situation too. So all the sarcasm that we hear is stressing the problem that exists on both sides: the world that ignores the problem and the people suffering who aren't being honest. So we're eased right into the refrain "we wear the mask," which makes it stand out in comparison to the rest of the poem.

In this poems Dunbar describes how the black people hopeless and lose everything what they have like a wise in more specific social life of the black man has broken and they has lose of the human right as a normally human it can be prove when the black man thinking sadness and affliction from the mistreatment of the white people but they just can use the mask in their life so that look like smile and the black man just surrender about that condition.

Pay it I will to the end Until the grave, my friend, Gives me a true release Gives me the clasp of peace. (The Debt 4-8)

In this poems the black people dreams when the affliction and mistreatmen ends, and they commence to ban them life and hoping that graveyard ended all of afflictions and give a really freedom that will be a barometer of they life if they are has died so that their life will be full of piece.

We smile, but, O great Christ, our cries

To thee from tortured souls arise.

We sing, but oh the clay is vile

Beneath our feet, and long the mile;

But let the world dream otherwise,

We wear the mask!

(We wear the mask 10-15)

"Smile" that covers everything up, reminding us that those phony masks are the real problem. The writer looks to be reaching for spiritual guidance ("O great Christ") and the chance for salvation ("souls arise"). The allusion to Christ emphasizes the author's need for help that the world will not provide. Additionally, the writer see more duality in line 10 that begins with "smile" and ends with "cries." So not only these are folks smiling through their pain but 
they're also singing. Again, here's more of an indication of something that appears to be content but isn't. The second half of line 12 works more with some of the biblical allusions we saw in the previous lines. The "clay" here is the earth but it may also be a reference to the origins of man. So the speaker is saying that they're singing through the pain while standing above the earth that's "vile" (wicked) because it provides only pain and suffering for these folks. And yet that vile earth is still their home/origins, which makes things even worse. Notice too that the language here has that same sort of emotional distress ("oh the clay is vile") that we saw in lines 10 and 11 ("O great Christ"). So at this point we're seeing behind the mask more fully and things are awfully sad back there. And yet those "feet" and the imagery of walking that long mile indicate that there's hope.

Dunbar ends his poem as a rondeau should, with another line ("otherwise") matching the first rhyme scheme of "lies/eyes/sighs," etc. "let the world dream otherwise." If the world is dreaming, it's safe to assume that people aren't savvy to what's really going on, mostly because the world chooses not to be. And by now we know what's really behind the mask: lies, cries, and pain that folks aren't being honest about. We also understand that the "masks" people wear, no matter what they look like, are not to be completely trusted. What can be trusted is honest discussion and the efforts people make to fix the hurtful and destructive stuff they see around them.

The black American just peforce accept that condition and situation and surrender all the thing of the God's hands. Although they in mistreatment and oppression in this poems Dunbar has showing the extraordinary depression because the black man just dreams to life freedom from the slavery.

I know why the caged bird beats his wing

Till its blood is red on the cruel bars;

For he must fly back to his perch and cling

When he fain would be on the bough a-swing;

And a pain still throbs in the old, old scars

And they pulse again with a keener sting

I know why he beats his wing!

(Sympathy 8-14)
"Sympathy" is a lyric poem about a caged bird that symbolizes oppressed black Americans specifically and any oppressed people generally. In this poems Dunbar describe what happen to the slavery in them work. The writer know why the slavery tortured and make unhumanity with the American white. In this poems is clearly Dunbar showing how brutal the wold of black people and has happen a discrepancy of the social life like a feel sick to mistreatment abuse verbally and make them lose of the Human Right and all the poems Dunbar telling to the reader how the result of the racialism.

This bird he's presenting to us is so unhappy, it's beating its wings against the bars until they bleed. Why is it doing that? Because it wants to fly from the cage, but it can't. How can its little wings break down those tough metal bars? Here, again, the speaker identifies himself with the bird, and with its struggle for freedom. $\mathrm{He}$, like the bird, wants to get free. Instead, the bird has to hang out on its little perch in the cage, clinging there because it has nowhere else to go.

The reference to the "old, old scars" here suggests that this isn't the first time the little birdie is beating its wings against the bars. It really, really wants to leave that cage, so much so that it keeps hurting itself. Each time the bird beats its wings against the bars, its old scars "pulse," or throb again. This suggests the idea of recurring pain. The bird suffers over and over again; its pain isn't limited. At the end of this second stanza, the author repeats to us again that he identifies with the bird's suffering.

3.3 The Effects of Social Slavery to Social Life in Dunbar's Five Poems

Slavery's existence has plagued human history for thousands of years. Slavery seems to fill a need to produce things at a vast scale. For the United States, that product was unquestionably cotton. Black Americans - both male and female - were traded as slaves to work the fields on large cotton plantations in the South. Slavery allowed free whites, individually and collectively, to feel power and control at the height of Western colonialism.

To most of the world, slavery is considered an oppressive institution and a shame in the history of modern United States. There is no denying that horrible atrocities and unspeakable cruelties against humanity have occurred under slavery in the USA however, I would argue that perhaps some good actually 
could have come out of slavery. The black people may not only have been the victims, but also the victors. Slavery has seemingly strengthened the institution of family as well as the bonds of the African American people as they struggled for equal and just rights in a land that espouses ideas of freedom and democratic living the though in reality America wasn't staying true to its word. The writer intends to the reader look at the effects of slavery and how it strengthened the Black people instead of weakening them by using several accounts of slavery, in particular, focusing on the writer argument that slavery has been a boon to Black people instead of the curse that it is commonly believed to be.

Why should the world be over-wise, In counting all our tears and sighs?

Nay, let them only see us, while

We wear the mask.

(We wear the mask 5-9)

In this lines we saw the rhetorical question that emphasized the truth behind the masks. So the author is saying here that, instead of the world seeing the truth, they see only the masks and the lies. And again the tone here in "let them" suggests that the world is being spared the truth, via ignorance, perhaps because the truth is harder to accept than the mask. But the author is reminding us that the people wearing the mask need to be more honest about their situation too. So all the sarcasm that we hear is stressing the problem that exists on both sides: the world that ignores the problem and the people suffering who aren't being honest. So we're eased right into the refrain "we wear the mask," which makes it stand out in comparison to the rest of the poems.

We smile, but, $\mathrm{O}$ great Christ, our cries

To thee from tortured souls arise.

We sing, but oh the clay is vile

Beneath our feet, and long the mile;

But let the world dream otherwise,

We wear the mask!

(We wear the mask 10-15)

"Smile" that covers everything up, reminding us that those phony masks are the real problem. The author then looks to be reaching for spiritual guidance ("O great Christ") and the chance for salvation ("souls arise"). The allusion to Christ emphasizes the author's need for help that the world will not provide. Additionally, the writer see more duality in line 10 that begins with "smile" and ends with "cries."

So not only are these folks smiling through their pain but they're also singing, here's more of an indication of something that happen power feeling to the American people although they feel sick. So at this point the writer seeing behind the mask more fully and things are awfully sad back there. And yet those "feet" and the imagery of walking that long mile indicate that there's hope.

I know why the caged bird beats his wing

Till its blood is red on the cruel bars;

( Sympathy 8-9)

I know why the caged bird sings, ah me,

When his wing is bruised and his bosom sore,

When he beats his bars and he would be free;

It is not a carol of joy or glee, ( Sympathy 15-18)

In this stanza the Author identifies himself with the bird, and with the struggle of freedom. He, like a bird, want to get free. Instead, the bird want to really leave the cage because its so much hurting itself. Each time the bird beats its wing against the bars.

This liryc poem tell about a caged bird that symbolizes oppressed black American Specifically and any oppressed people generally in this poems Dunbar is clearly showing how brutal the world of black people in America, happen discrepancy of the social life and any mistreatment abuse verbally and make the black people lose of the human right.

There the potent sorrow, there

the grief,

The pale, sad staring of life's

tragedy.

$$
\text { ( Life's Tradedy 6-8) }
$$

In this liryc so clearly so clearly any of mistreatment of American white to the black people in America, there are something tragic and have the bad inpact to social life of of the American black. For example any punishment was most often meted in response to disobedience or perceived infractions, but sometimes abuse was carried out to re-assert the dominance of the master or overseer over the slave. Treatment was usually harsher on large 
plantations, which were often managed by overseers and owned by absentee slaveholders, conditions permitting abuses.

This, this indeed is to be accursed, For if we mortals love, or if we sing, We count our joys not by what we have,

But by what keept us from that perfect thing

.(Life's Tragedy 13-16).

\section{CONCLUSION AND SUGGESTION}

Dunbar in his poems presents about Racialism Slavery as reflected in Paul Laurence Dunbars poems to social life is the different person and communities. Dunbar issues the realistic to the real life. Viewing back to those three Racialism Slavery that's kind of slavery in Paul Laurence Dunbar poems, kinds of racialism that can be found in the poems and the effect of social slavery to social life that can be found in the poems, all are really true and they take place wherever and even whenever they will be. Perhaps someone will say that it's indeed realistic since it talks about social problem. In the writer's mind, realistic in this case means, beside it's true of life, its also consistenly with condition that the author has set up.

First the writer found that slavery corrupted many whites who had authority over slaves, with the black people in America. Many kinds of social slavery happen in America reflected in Dunbars five poems that tell about full of regret, tragedy of life and happen inner depression morality in their life, its so terrible when the masters buyed the black people to be a slavery during of years employed them unhumanity and without salary, it's can to broken of their social life and lose of the human right.

Second, the writer found racial discrimination is one of the most controversial problems in our society. United States of America is one of the freest racist countries in the world. They believed that all the people in the world should have the same opportunities, same respect, and equality based reflected in Dunbars five poems such as the black people hopeless and lose everything what they have like a wise because of the brutal world to black people and has happen a discrepancy of the social life like a mistreatment abuse verbally, thinking sadness, affliction, from the
In this poems the writer describe about how to black people in America love of the themself and leaving some accursed that binding themself. However the black people get the racialism to the American white, they more and more strong to confront that. The writer also see how the black people believe still have a hope to get a freedom, that because the black people more have a struggle fighting get the freedom and human right.

mistreatment make the black people lose of the human right. Discrimination and prejudice and it is also the one that most related the writer experience. All the people in this world are human beings and should be treated with equality.

Third, The writer intends to the reader look at the effects of slavery and how it strengthened the black people instead of weakening them by using several accounts of slavery, in particular, focusing on the writer argument that slavery has been a boon to black people instead of the curse that it is commonly believed to be such as any kinds of mistreatment with unhumanity like by stressing, suffering, oppressed and discrepancy of the social life and any mistreatment abuse verbally and make the black people lose of the human right. So the writer want to conclude, however the readers get racialism from the another people we must strong to confront it, believe beside that there are something attractive.

The writer can to conclude is no discrimination, racialism between white skin and black skin because it's make the social life of the human is broken. We must remember all the human being have a same position and same place in God's eyes. The writer would like state that the black people and need more attention and we should help them to build their life.

4.2. Suggestions

The writer suggests that reading of poetry must recognize as an act of intelligence and understanding. Truly to know even what appears to be a simple poems call concentrated use of the faculties, and the greater the poem, the more acute must be.

The truth of poetry is the truth of an experience which the reader to know totally, emotionally, and rationally, with the number of its implication simultaneous ously explored. 
The writer took the poetry as his subject. First, a poem is entirelly viewed as only an expression of imagination, without consider furthemore its reflection of life and all its secrets. Poem can be introduced as a way to express something in every human being. Second, a poem has a different touch in giving people picture about the way how to see and to do a life. Third, a poem actually give more than what a science can do. Interpretations of science do not given an intimate sense of object as the interpretations of poetry give it. Fourth, a poem actually has a great relevant compotance in a rhetorical cummonication. One ask for the sake of offect to impress people. Poetry is able to rise basic social sense of a human being. Increase a willing to produce and socialize social looking poems. When people are often well covered with choices of values in their lives, perhaps social spirit and consciousness will be slowly sattle in their way of thinking. 


\section{Bibliography}

Allport, G.W. 1937. Personality: A Psychological Interpretation. New York: New York Publisher.

Atmazaki. 1990. Satra Teori \& Terapan, Padang: Angkasa Raya.

Douglass, Frederick. 1845. Narrative of the Life. New york: RGV Classic.

Dunbar. Dunbar Paul Laurence. 1987. Dunbar: Poem selected by David wright, New York: Penguin Books.

Freud, S. (1923). The ego and the id. SE, 19: 166.

Graff, Richard. 2005. "Prose versus Poetry in Early Greek Theories of Rhetorica Style. New york: SUNY Press.

Http : // en. Wikipedia. Org / wiki / Racism- in The- United- States, April 20th, 2017 at 21,30 Pm.

Hudson, William Hendry. 1983. An Introduction to The Study of Literature.

London: Foresman and Company.

Kellman, Steven G. 2006. Masterpieces of

American Literature,

http://www.enotes.com/topics/paul-laurence-

dunbar/critical-essays\#critical-essays-analysis,

November 30th, 2016 at 21,00 Pm.

Kleden. 1984. Teori \& terapan, Padang: Citra

Budaya Indonesia.

Lange, James. 1884. Theory of Emotion. New york: Oxford University.

Lincoln, Abraham. 1859. Speeech at Cincinati : Ohio.

Luxemburg, Jan Van, et. Al. 1986. Pengantar
Ilmu Sastra, PT Gramedia: Jakarta.

Pradopo, Rachmat Djoko, et.al. 2001. Metodologi Penelitian Sastra, Yogyakarta: PT Hanindita Graha Widia.

Mathews, James Newton. 1893. Oak and Ivy. Dayton, Ohio: United Brethern Publishing House.

May, Charles E. 2001. Short Fiction Masterpieces, California State: Ohio University.

Miller, Ruth and Robert A. Greenberg. 1981. Poetry, an Introduction. New York: St Martin's Press.

Pervin 2005. Personality: Theory and Research. New york: Wiley Publisher

Ram, Nilam. 2009. Theory of Psychology and Developmental. New york: Routledge.

Rasmuson, Elmer E. 2014. Library Research. Chicago: American Library Association.

Reisman Canfield, Rosemary M. 2011. American Poets Analysis, USA: Published by Salem Pr Inc.

Sylvan Barret, Marton Berman, William Burto. 1989. An Introduction to Literature. Ninth Edition. London: Scott, Foresman and Company.

Wellek, Rene and Austin Werren. 1956. Theory of Literature, New York: Pelican Books.

Www. History. Com / Topics / Black-history / Slavery, April 20th, 2017 at 21,00 Pm.

Www. History . Com / Topics / Black-history / Effect of Slavery, April 20th, 2017 at 21,20 Pm. 